\title{
Job Satisfaction among School Teachers in Duwakot, Bhaktapur District, Nepal
}

\author{
Manandhar $\mathbf{P}^{1}$, Manandhar $\mathbf{N}^{1}$, Joshi SK ${ }^{1}$ \\ 'Department of Community Medicine, Kathmandu Medical College Public Limited, Duwakot, Bhaktapur, Nepal
}

\section{ABSTRACT}

Introduction: Job satisfaction is one of the determinant factors for professionals. The job satisfaction concerning school teachers reflects their strong motivation towards their job. This study aimed to measure the job satisfaction among teachers of Government and Private schools of Changu Narayan Municipality.

Methods: A cross-sectional study was done at seven government and five private schools of wards no. 1 and 2 of Changu Narayan Municipality Bhaktapur District, Nepal over one month (20 th April $-19^{\text {th }}$ May 2021). Schools of Changu Narayan Municipality Ward No. 1 and 2 were purposively selected. The data was collected through validated questionnaire on Job Description Index (JDI) which consisted of 17 domains. Data were entered in Excel and data analysis was done in SPSS version 20.

Results: The overall job satisfaction was $65.77 \pm 11.52$ which indicated that the majority of teachers were highly satisfied with their job.

Conclusion: The findings of this study indicate job satisfaction among school level teachers who were satisfied in their occupation especially in teaching profession. The domain sources of job satisfaction in school teachers appear to be work itself, coworker, relationship with students and sense of achievement. Whereas motivation in profession is most likely to be less job satisfaction among Government and Private schools.

Key words: Job satisfaction, Likert scale, School teachers.

\section{Introduction}

Q uality education is an important backbone for any educational system. Teachers are the role models to students for providing knowledge, values, morality and to prepare them for future. Job satisfaction is one of the determining factors in any professional field. ${ }^{1}$ For school teachers, job satisfaction could be crucial factor for the good job performance leading to a good motivational approach reflecting effective and efficient teaching activities. ${ }^{2,3}$

DOI: https://doi.org/10.3126/ijosh.v11i3.39769

Conflicts of interest: None

Supporting agencies: None

Date of submission: 22.06.2021

Date of acceptance: 10.09 .2021

Date of publication: 30.09 .2021

\section{Corresponding Author}

Dr. Pratibha Manandhar,

Assistant Professor, Department of Community Medicine,

Kathmandu Medical College, Duwakot, Bhaktapur, Nepal

Contact no: 977-9803812216

E-mail: pratibhamanandhar@gmail.com

Orchid ID: https://orcid.org/0000-0003-2071-1347
Locke EA states that "Job satisfaction is a pleasurable or positive emotional state resulting from the appraisal of one's job or job experiences." 4 It serves as a mediator for creating a relationship between individual working conditions and organizational outcome. ${ }^{5}$ Various factors like job description, salary, promotion criteria, working peer-groups and personal factors like age, sex, marital status and years of experience could play a vital role in job satisfaction. ${ }^{6}$ The study done by Bhurtel T. et al in India revealed that Government (Govt.) school teachers are more satisfied in their job satisfaction than the private school teachers. ${ }^{7}$ Similarly another study conducted in Nepal concluded that teachers were experiencing high satisfaction with work, coworker and job in general among higher secondary school of Government and private school in different cities. ${ }^{6}$ This study aimed to find out and compare the job satisfaction among teachers of Government (Govt.) and Private schools of Changu Narayan Municipality.

\section{(c) (1) (8)}

This journal is licensed under a Creative Commons AttributionNon Commercial 4.0 International License. 


\section{Methods}

A cross-sectional study was conducted in seven Government and five private schools of ward no. 1 and 2 of, Changu Narayan Municipality, Bhaktapur District, Nepal from 20th April to 19th May 2021. Ethical clearance was taken from the Institutional Review Committee (Ref. 0504202110) of Kathmandu Medical College. The schools were purposively selected. The sample size of 163 was calculated by using the formula, $n=Z^{2} p q / d^{2}$. Where, $n=$ sample size, $Z=1.96$ for a confidence interval of $95 \%$, prevalence of job satisfaction $(p)$ was $57 \%,(0.57)^{6}, q=1-p=0.43, d=$ margin of error (here, the value taken as $8 \%(0.08)$ making 147 and taking a 10\% non-response rate, the final sample size was 163 .

Sixty-eight teachers were enrolled from the Government schools and 95 teachers were enrolled from private schools by stratified random sampling technique. Permission was taken from the school authority. Written informed consent was obtained from all Government and Private school teachers participating in this study.

The validated questionnaire based on Job Description Index (JDI) ${ }^{8}$ was used which consisted of 17 domains towards job satisfaction. The JDI is a 5-point Likert scale. ${ }^{9}$ The domains were recognition- to receive honor from principal and students from school, potential for proficient development- improving one's own professional skills, job of achieving success, work itself, interpersonal relationship with colleague and administration, overall level of satisfaction with job, job security, responsibility towards job- sincerity, relationship with students, their dedication towards job, level of job satisfaction.

Questionnaires were completed by teachers from their respective schools at their convenient locations (on school campuses). The completed questionnaires were subsequently collected by a consenting third party to remove observer bias.

Descriptive statistics were used to measure the level of job satisfaction. Data were entered in Excel and data analysis was done in Statistical Package for Social Science (SPSS) version 20. An independent sample t-test was used to study the significant difference between the mean score of Government vs Private Schools and $p$-value $<0.05$ was considered as significant.

\section{Results}

Majority $116(71.2 \%)$ of the respondent were female and most of the teachers were Hindu 156 (95.7\%). One hundred and thirty teachers $(79.8 \%)$ were married and $102(62.6 \%)$ belonged in nuclear families. Their school status showed that $71(43.6 \%)$ have a bachelor degree. About half of the respondents 84 (51.5\%) taught at the (6th $-10^{\text {th }}$ grade) secondary level and most of the them $58(35.6 \%)$ have teaching experience of more than ten years. (Table 1)

The Mean and Standard Deviation of teachers' job satisfaction in Government and Private schools were significant in various domains. The result indicates most of the Job satisfaction domains were greater than 3, showed "interpersonnel relationship" domain among the private school teachers had the highest job satisfaction level (mean 4.13 \pm 0.64 ) except in "received award" and "motivation in profession" domains. Thus this study found that the mean value for job satisfaction of teachers among Government school and Private school were $62.81 \pm 12.56$ and $66.13+10.04$ respectively. There is a significant relationship between Government and Private School teachers regarding various job satisfaction domains like interpersonnel relationship, sense of achievement, level of satisfaction and job security (Table 2).

Table 1: Sociodemographic profile of the teachers working in Government and Private schools $(n=163)$

\begin{tabular}{llccc}
\hline Socio demographic profile & $\begin{array}{c}\text { Government school } \\
(\mathbf{n})(\%)\end{array}$ & $\begin{array}{c}\text { Private school } \\
(\mathbf{n})(\%)\end{array}$ & $\begin{array}{c}\text { Total } \\
\mathbf{n}(\%)\end{array}$ \\
\hline \multirow{4}{*}{ Age } & $<29$ & $10(6.13)$ & $50(30.67)$ & $60(36.80)$ \\
& $30-39$ & $26(16)$ & $31(19)$ & $57(35)$ \\
\multirow{2}{*}{ Gender } & $40-49$ & $13(8)$ & $9(5.5)$ & $22(13.50)$ \\
& $>50$ & $19(11.6)$ & $5(3.1)$ & $24(14.70)$ \\
& Male & $27(16.5)$ & $20(12.3)$ & $47(28.8)$ \\
& Female & $41(25.1)$ & $75(46.1)$ & $116(71.2)$
\end{tabular}




\begin{tabular}{|c|c|c|c|c|}
\hline \multicolumn{2}{|c|}{ Socio demographic profile } & $\begin{array}{l}\text { Government school } \\
\text { (n)(\%) }\end{array}$ & $\begin{array}{l}\text { Private school } \\
\text { (n)(\%) }\end{array}$ & $\begin{array}{l}\text { Total } \\
\text { n (\%) }\end{array}$ \\
\hline \multirow{3}{*}{ Caste } & Brahmin & $32(19.7)$ & $44(26.9)$ & $76(46.6)$ \\
\hline & Chhetri & $17(10.4)$ & $27(16.6)$ & $44(27.0)$ \\
\hline & Janajati & $20(12.2)$ & $23(14.2)$ & $43(26.4)$ \\
\hline \multirow{3}{*}{ Religion } & Hindu & $65(39.8)$ & 91 (55.9) & $156(95.7)$ \\
\hline & Buddhist & $0(0)$ & $2(1.2)$ & $2(1.2)$ \\
\hline & Christian & $3(1.9)$ & $2(1.2)$ & $5(3.1)$ \\
\hline \multirow{2}{*}{ Family } & Nuclear & $40(24.5)$ & $62(38.1)$ & $102(62.6)$ \\
\hline & Joint & $28(17.2)$ & $33(20.2)$ & $61(37.4)$ \\
\hline \multirow{3}{*}{ Marital status } & Married & $63(38.6)$ & $67(41.1)$ & $130(79.8)$ \\
\hline & Separated & $1(0.6)$ & $3(1.9)$ & $4(2.5)$ \\
\hline & Unmarried & $4(2.4)$ & $25(15.4)$ & $29(17.8)$ \\
\hline \multirow{3}{*}{$\begin{array}{l}\text { School level (work } \\
\text { place) }\end{array}$} & Elementary school & $43(26.3)$ & $27(16.6)$ & $70(42.9)$ \\
\hline & Secondary School & $21(12.9)$ & $63(38.6)$ & $84(51.5)$ \\
\hline & Higher secondary school & $4(2.4)$ & $5(3.1)$ & $9(5.5)$ \\
\hline \multirow{4}{*}{ Teachers education } & Secondary & $13(7.8)$ & $2(1.2)$ & $15(9.0)$ \\
\hline & Higher secondary & $18(11.1)$ & $18(11.1)$ & $36(22.2)$ \\
\hline & Bachelor & $20(12.2)$ & $51(31.4)$ & $71(43.6)$ \\
\hline & Master & $17(10.4)$ & $24(14.7)$ & $41(25.2)$ \\
\hline \multirow{4}{*}{ Teaching experience } & $<10$ years & $11(6.6)$ & $47(28.8)$ & $58(35.6)$ \\
\hline & $11-20$ years & $15(9.2)$ & $26(15.9)$ & $41(25.2)$ \\
\hline & $21-30$ years & $11(6.7)$ & $7(4.4)$ & $18(11)$ \\
\hline & $>31$ years & $31(19.0)$ & $15(9.2)$ & 46 (28.2) \\
\hline
\end{tabular}

Table 2: Descriptive statistics of Domains of Teacher's Job Satisfaction by schools $(n=163)$

\begin{tabular}{|c|c|c|c|}
\hline \multirow{2}{*}{ Domains of Job Satisfaction } & \multirow{2}{*}{$\begin{array}{c}\text { Government School } \\
\text { Mean (SD) }\end{array}$} & \multirow{2}{*}{$\begin{array}{l}\text { Private School } \\
\text { Mean (SD) }\end{array}$} & \multirow{2}{*}{ P-value } \\
\hline & & & \\
\hline Recognition & $3.53(0.80)$ & $3.76(0.74)$ & 0.039 \\
\hline Potential & $3.68(0.81)$ & $3.97(0.55)$ & $0.001^{* *}$ \\
\hline Supervision & $3.47(0.88)$ & $4.01(0.49)$ & $0.001^{* *}$ \\
\hline Interpersonel relationship & $3.81(0.17)$ & $4.13(0.64)$ & $0.001^{* *}$ \\
\hline Job security & $3.62(1.10)$ & $3.73(0.81)$ & $0.001^{* \star}$ \\
\hline Job status & $3.78(0.68)$ & $3.87(0.55)$ & 0.56 \\
\hline Experiencing success & $3.71(0.62)$ & $3.86(0.57)$ & 0.70 \\
\hline Working condition & $3.66(0.88)$ & $3.81(0.60)$ & 0.004 \\
\hline Teacher evaluation & $3.57(0.77)$ & $3.99(0.61)$ & $0.001^{* *}$ \\
\hline Responsibility & $3.99(0.53)$ & $4.02(0.56)$ & 0.718 \\
\hline Work itself & $3.96(0.50)$ & $4.08(.45)$ & 0.276 \\
\hline Factors in personal life & $3.74(0.80)$ & $3.89(0.59)$ & $0.001^{* *}$ \\
\hline Relationship with student & $3.99(0.78)$ & $4.12(0.50)$ & 0.99 \\
\hline Sense of accountability & $3.93(0.65)$ & $4.00(0.52)$ & 0.83 \\
\hline Sense of achievement & $3.74(0.56)$ & $4.00(0.61)$ & $0.001^{* *}$ \\
\hline Level of satisfaction & $3.63(0.77)$ & $4.02(0.56)$ & $0.001^{* *}$ \\
\hline Motivate in profession & $1.15(0.35)$ & $1.06(0.24)$ & $0.001^{* *}$ \\
\hline Over all job satisfaction & $62.81(12.56)$ & $66.13(10.04)$ & \\
\hline
\end{tabular}

** significant at $1 \%$ level of significant. 


\section{Discussion}

Job satisfaction is one of the important aspect in everyone's carrier. Job satisfaction will help to work further responsible and accountable in their working status which ultimately helps to bloom their career as a successful teacher. This study was conducted to find out the job satisfaction level among the Government and Private school teachers of Changu Narayan Municipality. One hundred and sixty three teachers of seven Government and five private schools were enrolled in current study. Most of the domains have positive responses both in Government and private school teachers and they were satisfied in their job. The mean score of Job satisfaction domains were mostly higher among Private school teachers as compared to Government. There was highest mean score in "interpersonnel relationship" and "relationship with students" among private school teachers.

On comparing Government and Private schools teachers Job satisfaction in our study, most of the domains were similar. Domains like "responsibility $3.99 \pm 0.53$ " and "relationship with students $3.99 \pm 0.82$ " are the most observed highest mean score in Government school teachers whereas domains like "Interpersonal relationship 4.13 $\pm 0.64 "(p<0.001)$ and "relationship with students $4.12 \pm 0.50 "(p=0.99)$ were the highest observed among Private school teachers. This highlighted that there is a decent relationship between teachers and students among both the Government and private schools. Our findings are intimately verified by Veldman et al ${ }^{10}$ in which teachers' job satisfaction was positively related to relationships with students.

A study conducted by Bhurtel et al in Haryana, India found that means of various job satisfaction domains eg. "enjoy at work", "interesting \& challenging work", "satisfied with job" and "job responsibilities" were $4.53 \pm 0.61, \quad 4.47 \pm 0.61, \quad 4.33 \pm 0.87$ and $4.48 \pm 0.61$ respectively. ${ }^{7}$ Whereas, in our study, domains mean of "relationship with students", "work itself", and "interpersonal relationship" were $4.12 \pm 0.50,4.08 \pm 0.45$ and $4.13 \pm 0.64$ respectively highlighting the various domains of job satisfaction among school teachers. This shows that the teachers in various places including Nepal enjoy their job and they are happy and satisfied in their occupation.
Similarly, Thadathil BJ in Nepal reported high job satisfaction among school teachers in the following domains like "enjoy the job ( $M=4.23 \pm 0.84: 4.36 \pm 0.76)$ " followed by "like colleagues ( $M=4.45 \pm 0.84: 4.49 \pm 0.78$ )" and "sense of pride ( $M=4.39 \pm 0.86$ : $4.44 \pm 0.88$ )" whereas, less job satisfaction was noted in "hours of work $+(\mathrm{M}=2.25 \pm 0.93$ : $2.45 \pm 1.18)$ " among Govt. and private school. ${ }^{11}$ In our study "relationship with students, work itself and responsibility" had a higher job satisfaction level. Likewise domain to motivate in profession $(1.15 \pm 0.35: 1.06 \pm 0.24)$ has less job satisfaction. The reason behind this less job satisfaction could be due to not receiving rewards, long hours of work and not motivation towards job.

The study done by Thadathil BJ accepted that the overall level of job satisfaction among government and private teachers in Nepal is high. ${ }^{11}$ The findings were similar in this study too. The reason behind higher job satisfaction in our study could be due to dedication to providing better education to students for their future life.

\section{Conclusion}

The findings of this study indicate job satisfaction among school level teachers was satisfied in their occupation especially in teaching profession. The domain sources of job satisfaction in school teachers appear to be work itself, coworker, relationship with students and sense of achievement. Whereas motivation in profession is most likely to be less job satisfaction among Government and Private schools. Though job satisfaction was observed higher in both Govt. and private schools in our study, for continuity of this job satisfaction, granting rewards and promotions, conducting teacher's training, and providing recreation facility will have motivation in profession.

\section{Acknowledgement}

We would like to acknowledge all the school teachers of Government and private schools of ward no. 1 and 2 of Changu Narayan Nagarpalika, Bhaktapur for their voluntarily kind participants in this study. At last but not the least, our sincere thanks to Mr. Ram Sharan Neupane for his logistic support during the data collection. 


\section{References}

1. Jahan M, Ahmed M Md. Teachers' job satisfaction: $A$ study in secondary schools of Bangladesh. Journal of Contemporary Teacher Education. 2018;11(1):71-91. [Full Text]

2. Chamundeswari S. Job satisfaction and performance of school teachers. International Journal of Academic Research in Business and Social Sciences. 2013;3(5):420-8. [Full Text]

3. Patel KK. A study of Job Satisfaction of Primary School teachers. International Journal of Research in all Subjects in Multi Languages. 2017;5(5):7-9. [Full Text]

4. Locke EA. What is job satisfaction?. Organizational Behavior and Human Performance. 1969;4(4):30936.

5. Dorman B, Zapf C. Job satisfaction among hospital doctors in Norway and Germany: A comparative study. National Sample Health Journal. 2001;37(3):503-8.

6. Kayastha DP, Kayastha R. A Study of job satisfaction among Teachers, Higher Secondary School of Nepal.
International Journal of Evaluation and Research in Education (IJERE). 2012;(1)1:41-4. [Full Text]

7. Smith PC, Kendall LM, Hulin CL. The measurement of satisfaction in work and retirement a strategy for the study of attitudes. Chicago III,Rand McNally. 1969.

8. Likert R. A technique for the measurements of attitudes. Archives of Psychology. 1932; 140(22):555.

9. 9. Veldman L, Tartwijk JT, Brekelmans M,Wubbels T. Job satisfaction and teacher-student relationships across the teaching career: Four case studies Teaching and Teacher Education. 2013;3(2):5565. Available from:https://doi.org/10.1016/j. tate.2013.01.005.

10. Tilak R, Lalita. International journal of social science \& interdisciplinary research. 2013;2(9):151-8. [Full Text]

11. Thadathil BJ. Job Satisfaction among Teachers in Nepal: A Comparative Study between Government and Private Schools. International Journal of Science and Research. 2017; 6(8):727-9. [Full Text] 